\title{
Editorial
}

\section{Japanese international anti-tax avoidance legislation - background of selected 1992 Japanese tax reform provisions}

Toshiaki Katsushima, Deloitte Touche Tohmatsu, Tokyo, Japan

After a detailed study, significant amendments to the Japanese income tax law were submitted to the Japanese Diet. These amendments were approved on 28 March 1992 and enacted into law on 31 March 1992 as part of the 1992 Japanese tax reform. Many of the changes enacted were primarily in response to three factors for short- and mid-term objectives; The continuous increase in the aged population in Japan as it approaches the 21st Century; Japan's contributions in international areas such as its contributions to the United Nations in support of the organization's world peace activities; and the slow-down in the Japanese economy in recent years. These three factors create a need for funds that, arguably, may not be met under the current Japanese income tax regime.

This environment led to anticipated revenue raising tax amendments that include material changes in two areas that may have a major impact on Japanese international in-bound and out-bound operations. These two areas are, respectively, (i) the introduction of domestic thin-capitalization tax legislation and (ii) the changes to Japan's tax haven rules.

\section{Thin-Capitalization}

Previously, Japanese domestic income tax law did not provide for thin-capitalization. Outside of limitation on the deductibility of interest paid to foreign corporations under Japan's transfer pricing laws and possible limitations in accordance with Japan's income tax treaties, interest paid to a foreign related party was generally fully deductible for Japanese corporate tax purposes. Under the new law, foreign owned Japanese corporations and Japanese branches of foreign corporations that are viewed as being "thinly capitalized" may be denied a tax deduction for interest paid to a foreign related party to the extent that the Japanese corporation (or head office of the Japanese branch) is thinly capitalized. The debt-to-equity ratio is, in principle, 1 to 3 .

\section{Tax Havens}

Under prior Japanese income tax law, a 10 per cent or greater Japanese shareholder of a foreign corporation that is more than 50 per cent owned by Japanese shareholders may be required to include its share of the income of such foreign corporation in Japanese taxable income if the foreign corporation is established in a Japanese Ministry of Finance designated tax haven. Under the new tax haven provisions, the 50 per cent test continues to apply. However, the 10 per cent shareholder test is decreased to 5 per cent and the designated tax haven country concept has been replaced by a 25 per cent income tax rate test. It may be argued that the reason for the change from the designated list to the effective income tax rate concept is the time needed to have a jurisdiction designated as a tax haven (lost revenue due to time lag) and diplomatic implications associated with designating a country as a tax haven.

Both the above provisions are designed to result in increased tax revenues for Japan. As is explained above, it is my view that the main purposes of the amendments are to raise revenues to meet the perceived funding needs caused by the three factors noted above. The success of these tax changes in meeting their objective, and their acceptance by Japan's trading partners will only be known after the passage of time. 